\title{
Sir Gruffydd Llieryd
}

QIR GRUFFYDD LLWYD has long been one of the most elusive f figures in medieval Welsh history. ${ }^{1}$ The following notes are offered in the hope of throwing a little new light on his career.

The Welsh pedigrees give the hero's full name as Gruffydd ap Rhys ap Gruffydd ap Ednyfed Fychan, and he is usually described as lord of Tregarnedd in Anglesey and of Dinorwig in Carnarvon. ${ }^{2}$ His name, and his connexion with Tregarnedd, are vouched for by an entry in the Close Roll of $1297^{3}$ That, however, is not his first appearance in Chancery records. As early as May 1284, 'Griffin son of Rhys son of Griffin son of Edenevet' is described as succeeding his father in various lands in the cantred of Rhos." If, therefore, it can be proved that this Gruffydd ap Rhys ap Gruffydd ap Ednyfed Fychan, and Gruffydd Llwyd are really one and the same person, the fact of Gruffydd Llwyd's existence, at any rate, will have been established on definite evidence.

After the conquest and settlement by Edward I, Wales became one of the king's great recruiting grounds, and from 1298 onwards two names constantly appear in connexion with the raising of troops in North Wales, chiefly for the Scottish wars. These two names are 'Griffin ap Res' and 'Griffin Thloyt', or obvious variants. Thus 'Griffin ap Res' is described in 1298 as having been the leader of the Welshmen of North Wales in the recent expedition to Flanders, ${ }^{5}$ and he is appointed at various times

1 Twenty yeara ago Professor Tout gave a cantious summary of the traditional story in a short erticle contributed to the Dictionary of National Blography. In his lateat work he writes that 'Sir Gruffydd Llywd, of Tregarnedd, the bardic hero of Welsh resistance to Edward II, is still of unproved historicity': The Place of Edward $I I$ in English History, p. 210.

- Dwnn, Heraldic Visitations, ii. 101 ; Pennant, Tours in Wales (ed. 1883), iii. 49-50. Gruffydd Llwyd thus belonged to a noble Welsh family, for Ednyfed Fychan was the 'senesche]' and chief counsellor of Llywelyn the Great: Dict. of Nat. Biog., s.v. Ednyved Vychan. Ednyfed's wife was Gwenllian, daughter of Rhys ap Gruffydd, the powerful 'Lord Rhys ' of Dinefwr in Henry II's roign.

3 Cal. of Close Rolls, 21 August 1297, pp. 57-8: Order to John do Havering, justice of North Wales, to deliver to Griffin son of Rhys son of Griffin son of Edenevet certain lands in Tregarneth in Anglesey which Margaret, late the wifo of Rhys, held in dower of the gift of Rhys, and which the justice has taken into the king's hands by reason of hor death.

- Cal. of Chancery Rolls, Various (Welsh Rolls), p. 293.

- Cal. of Patent Rolls, 15 March 1298, p. 335. Ho had gone over with the king in Angust 1297, riding a horse worth 25 marks: Public Record Office, Exchoquer Accounts, 6/37. 
afterwards to levy and lead men from North Wales to Scotland." During the same period 'Griffin Thloyt' appears engaged in a similar capacity. ${ }^{7}$ On 5 August 1309 orders were issued to ' Roger Mortimer, justice of Wales, Gruffydd ap Rhys, and Iorwerth ap Gruffydd' to choose a stated number of footmen from North Wales; on 11 September these orders were cancelled, and new letters were issued ordering ' Roger Mortimer, Justice of Wales, Gruffydd Llwyd, and Iorwerth ap Gruffydd' to levy a smaller number of men instead. ${ }^{8}$ These facts establish the identity of Gruffydd ap Rhys and Gruffydd Llwyd. It is equally certain that he was a knight. The tradition that hé was knighted by Edward I on bringing to Rhuddlan the news of the birth of Edward of Carnarvon is probsbly fictitious, sut he was certainly 'Sir Griffin Thloyt, knight', when he paid homage at Flint to Prince Edward in April $1301 ;{ }^{10}$ and again in 1318 , for example, he is described as 'Griffin ap Rees, miles '." Nor can there be any doubt that this Sir Gruffydd ap Rhys, otherwise Sir Gruffydd Llwyd, was Gruffydd ap Rhys ap Gruffydd ap Ednyfed Fychan. For it is known that his great-grandfather Ednyfed Fychan held Llansadwm in Carmarthenshire and Llanrhystud in Cardiganshire. ${ }^{12}$ Both these places were in the possession of 'Gruffydd Llwyd ap Rhys' at his death in 1335, and devolved upon his son and heir Ieuan. ${ }^{13}$

These preliminary considerations-especially the fixing of the date of his death in 1335-raise the crucial question concerning Sir Gruffydd Llwyd. According to the traditional story, he ' lived long on friendly terms with the English, but grew disgusted with their oppressions', vainly tried to negotiate an anti-English alliance with Edward Bruce in Ireland, and finally, in 1322 or

- E. g. 27 May 1306, Cal. of Patent Rolts, p. 435; 5 Angust 1309, Rotuli Sootiae (Rocord Commission), it. 67-9 ; 24 Maroh 1314, ibid., p. 120.

1 E. t. 9 April 1298, Cal. of Patent Rolls, p. 342 ; 2 Juno 1301, tbid., p. 698 ; 7 June 1307, ibid., p. 529; 1 July 1308, ibid., p. 82 ; 15 June 1310, Rotuli Scatiae, i. 85. In the Soottish expedition of 1301 , 'Dominus Griff. Thleut, miles' rode a horse worth 20 marks 'in comitiva Principis Wallie', attended by three valets : P.R.O. Exohequer Acots. 9/23. In the expedition of 1306, similarly attended, he rode a horse worth 101. ' in familiz Principis ' : P.R.O., Exchequer Accounts, 13/7.

- Rotuli Scotice, i. 67-8, 72, 73. Sevfral gimilar coincidences ocour elsewhere: e. g. P.R.O., Ancient Petitions 7854 and 8154, both relating to the advowson of the church of Llanrhystad, and addresed to the king, the one by 'Griffutz ap Rees', the other by 'Gruffuth Loid '.

- At least he is not called miles in August 1297 in the inventory of horses for the expedition to Flanders : P.R.O., Erohequer Accounts, 6/37. The story that he brought the news of Edward of Camarvon's birth goes back at least to the daye of Loland, bat acoording to Loland his reward was not knighthood, but a grant of the manor of Dinorwig: Itinerary in Wales (ed. L. Toulmin Smith), p. 79.

10 Cal. of Patent Rolls, 6 March 1344, p. 228 : exemplification of a rocord mado in 1301 by the treasurer and barons of the exchequer.

"Rotuli Scotiae i. $197 . \quad$ Cal. of Patent Rolls, 4 October 1229, p. 271.

2 Cal. of Inquisitiones post Mfortem, vii. 403. 
thereabouts, rose in revolt, ' but was defeated by a great English army, taken prisoner, and shut up in Rhuddlan castle '. ${ }^{14}$ It is certainly true that he lived long on good terms with the English. It has been seen that for many years after 1298 he was practically the king's resident commissioner of array in North Wales; between the years 1301 and 1316 he acted at various times as sheriff in Carnarvon, Anglesey, and Merioneth ; ${ }^{15}$ from 1307 to 1317 he was forester of North Wales. ${ }^{16}$ His friendliness towards the English king is plain enough : is the tradition of his revolt as well founded?

The tradition itself is of gradual growth. Humfrey Lhoyd's History of Cambria ${ }^{17}$ gives only a meagre six lines to Sir Gruffydd Llwyd, and does not even suggest that his movements 'about 1322 ' amounted to a rebellion. What he says is, in fact, simply taken from Holinshed. ${ }^{18}$ Evidently neither Lhoyd nor his editor Powel had heard of any negotiations with Edward Bruce, or of imprisonment in Rhuddlan. When, however, Wynne in 1697 reissued Lhoyd's History with additions, he gave a much more circumstantial account of Sir Gruffydd $\mathrm{Llwyd},{ }^{19}$ substituting for Powel's tag from Holinshed the story that has now become traditional, including not only the statement that Llwyd, before his rebellion, had successfully negotiated with Edward Bruce, but also the actual correspondence that was alleged to have passed between them. In his preface, Wynne declares that he made the additions ' chiefly out of the notes of that late great antiquarian, Mr. Robert Vaughan of Hengwrt '. ${ }^{20}$ Those documents are now apparently lost, ${ }^{21}$ but by a lucky chance Vaughan's note on Sir Gruffydd Llwyd was quoted by Evan Evans in 1764 in his Specimens of the Poetry of the Ancient Welsh Bards. ${ }^{22}$ A comparison of the texts shows that Wynne, while substantially reproducing Vaughan's note, has made one important alteration. He

1" Dict. of National Biography, 8.v. Griffth Llwyd.

C as He was eheriff of Carnarvon from Easter to Micheolmas 1301, from Michaolmas 1304 to Michselmas 1305, and for the three years ending Micheelmas 1310 ; P.R.O., Ministers' Accounts, 1227/5, 1211/2 ; Pipe Roll 176, mm. 54-6; the accounts for 1301-4 are not extant. He was sheriff of Anglesey for the year ending Michaelmas 1306 : Pipe Roll 176, m. 53. He was sheriff of Merioneth from Michselmas 1314 to Michrelmas 1316 ; Pipe Rolls 170, m. 55, and 163, m. 30. In case he received the usual foo of 20l. per annum.

16 See the chamberlain of Carnarron's accounts for the period Michaelmas 3 Ed. II to Michselmas 11 Ed. $\Pi$, enrolled in Pipe Rolls 176, mm. 54-6, 170, m. 55, and 163, m. 30. The forester receired a wage of $7 \mathrm{t} d$. per day,

17 Edited with additions by David Powel, and published in 1584. I cite the reprint of 1811.

23. Op. cil., p. 281 : cf. Holinshed (ed. 1807), iii. 565.

10 William Wynne, History of Wales, pp. 310-13. 20 Vaughan died in 1687.

21 Some were incorporated by Ellis in his fragmentary edition of Sir John Price's Description of Wales, published at Oxford in 1663 : see Hearne's note prefixed to the British Museum copy.

- Pp. 46-7. Stephens quoted it from Evans in his Literature of the Kymry (ed. 1849), pp. 463-4. 
has interpolated the two letters. Their origin will probably never be known, ${ }^{23}$ but $W y n n e$ must at any rate stand sponsor for them. The one further addition necessary to round off the whole story was made in due course. Vaughan, followed by Wynne, had said no more as to Gruffydd's fate than that he 'was taken prisoner'; Pennant naturally enough added 'and doubtless underwent the common fate of our gallant insurgents ', ${ }^{24}$ and later writers went on to the definite statement that the luckless rebel 'was taken prisoner and conveyed to Rhuddlan, where he was soon afterwards beheaded '.25 It is Vaughan, however, that must be held primarily responsible for the Gruffydd Llwyd tradition. The Bruce letters and the hero's alleged execution are, after all, 'mere corroborative detail intended to give artistic verisimilitude to a bald and unconvincing narrative'.

It is therefore necessary to revert to the oldest and shortest form of the story as given by Lhoyd, whose account, we have seen, is a mere transcript from Holinshed, rather unintelligently wrenched from its context. The purport of the original is really quite clear. Holinshed is describing Edward II's victorious march along the Welsh border in the winter of 1321-2, and how various rebellious barons submitted and were consigned to custody. Then 'the Welshmen with their captain Griffin Loitis took the castles in Wales which were kept by the people of lord Mortimer the elder; they took also the castles of Mole, Chirk, and Olono, ${ }^{26}$ the keepers whereof, coming to the king to Shrewsbury, submitted themselves to him, who shortly afterwards sent them to the Tower of London'. Mortimer of Chirk, justice of Wales, had for the last twelvemonth been one of the king's leading, enemies, and what Holinshed means to say is that Llwyd and the Welshmen were attacking him in the king's interest-in other words, that Gruffydd, so far from being a rebel, was the leader of the royalist party among the Welsh of North Wales. Such is also the view established by the independent and unimpeachable evidence of the public records.

With the loss of his sheriffdom of Merioneth in $1316,{ }^{27}$ and of his forestership of Snowdon in the following year ${ }^{28}$ - official

\footnotetext{
- The statement in the preface implies that some of the additions were not derived from Vaughan.

"Tours in-Wales (ed. 1883), iii. 00.

w Soe, for example, the article on 'Llangevni ' in Levis' Topographical Dictionary of Wales (ed. 1848), ii. 38-40.

is So Holinshed. One would naturally suppose the name to be a misprint for 'Clono', but it is difficult to see why Clun should be' attacked, because it belonged to the earl of Arundel, who was a royal partisan. Possibly Holt, which was oallod 'Castrum Loonis' in the middlo ages, was intended; it belonged to Lancester in 1322, and was almost certainly atteaked by Sir Gruffydd : soe Cal. of Patent Ralls, $1321-4$, p. 122 .

$\pi$ Pipe Roll 163, m. 31. He was succeeded by John Cam.

4 Succeded on $25 \mathrm{May} 1317$ by John atte Wode : Pipe Roll 164, m. 35.
} 
changes which may very well have been due to some fluctuation of parties across the border-Gruffydd, for a time at least, was no longer employed in civil administration. Nevertheless, his old ties with the king, formed in the days when he had ridden on expeditions to Scotland 'in familia Principis,' 29 remained unbroken and the royal confidence unimpaired. In November 1318 the king, 'with the assent of the parliament at York,' granted to the younger Despenser the important district of Cantref Mawr in Carmarthenshire, together with other lands in South Wales. To give effect to this grant, he dispatched into those parts hig yeoman Rhys ap Gruffydd accompanied by 'Griffin Thloyt '.00 His appointment on this business, which so nearly concerned the court party, proves that he was trusted by the king. It is not surprising, therefore, to find him in 1322 leading the men of North Wales in an attack on his master's enemy, the lord Mortimer of Chirk. Nor did he then act on his own responsibility. He was the legally accredited representative of the king. He had been appointed, early in November '1321, 'to levy all forces, horse and foot, in North Wales to suppress any insurrection in those parts ' $;{ }^{31}$ and on the 30th. he was ordered, after suppressing any such 'insurrection', to come to the king with his troops. ${ }^{39}$ He was therefore only obeying orders when he took part in the attacks on the castles of Holt, Chirk, and Welshpool, and in the case of the last two strongholds he was formally appointed along with two others to receive custody of them in the king's name. . $^{33}$

His loyalty was rewarded by continued manifestations of the king's confidence. On 16 November 1321 he was reappointed to his old office of sheriff of Merioneth, ${ }^{34}$ which he kept till $1327 .{ }^{35}$ He was made keeper of the forfeited castle, town, and lands of Builth, ${ }^{36}$ and of the castle and land of Llandovery. ${ }^{37}$ Immediately after the short campaign of $1321-2$ he once more received a commission to raise and lead troops from North Wales to the Scottish expedition. ${ }^{38}$ In August 1323 he was entrusted with

"See above, p. 590, note 7. He is called 'Griffin Thowit, the Prince's knight,' in June 1307 : Cal. of Patent Rolts, 7 June 1307, p. 529.

20 Cal. of Paient Rolls, 21 November 1318, pp. 255-6.

"Ibid., 15 November 1321, p. 35.

"Cal. of Close Rolls, 30 November 1321, p. 507.

24 Cal. of Patent Rolls, 16 January 1322, p. 49 ; ibid., 18 January 1322, p. 48. For Holt, seo ibid., 27 May 1322, p. 122, which makes it very probsble that Gruffydd had a hand in attecking that castle.

34 Broese, Kalendars of Groymedd, p. 68.

2s He accounts and drews pay from Michalmas 1321 to Michsolmas 1327 : Pipo Rolls 168, m. 47 ; 169, m. 44; 171, m. 40 ; 173, m. 45.

34 Mentioned as Keeper, Cal. of Close Rolls, 23 January 1322, p. 416 ; and egain, ibid., 20 March 1324, p. 81.

"1 Mentioned as Keeper, ibid., 21 July 1322, p. 577.

a Cal. of Patent Rialls, 14 February, 1322, p. 73 ; ibid., April 22, 1322, p. 78.

VOL. XXX. - NO. OXX. 
the levy of troops in North Wales to provide against possible dangers that might result from the escape of Mortimer of Wigmore from the Tower. ${ }^{3 \theta}$ He received a similar charge in September 1326 when Isabella and Mortimer invaded the realm. ${ }^{40}$ He thus clearly stood high in the king's favour. What, therefore, becomes of the traditional story of his revolt? Mr. Tout long ago expressed the opinion that Llwyd's political importance had been 'exaggerated '. It would be more true to say rather that it has been misunderstood. For the old story of a rebellion in 1322 is clearly due to a misconception. Gruffydd was no anti-English leader, as Vaughan and others after him have supposed. He himself acted simply as a royal partisan, and there is no evidence that his followers were actuated by any desire to overthrow English government in Wales. The real importance of his movements is that they assisted to no small degree in bringing about the collapse of baronial opposition to Edward II in the march. It has always been difficult to understand why the elder Mortimer and his party should have made such poor resistance to the king in 1322. The explanation is to be found largely in the fact that they had to face a simultaneous attack from the king on one flank and from Gruffydd Llwyd's Welshmen on the other, and that the success of the latter in capturing Chirk undermined the very centre of Mortimer's power.

The fall of Edward II meant the discomfiture of the party to which Gruffydd had long been closely attached, and might be expected sooner or later to react unfavourably upon his position. That did not, however, happen immediately in his case. He kept his sheriffdom of Merioneth until about Michaelmas 1327.4 Accordingly, when representatives from North Wales were summoned to the parliament of January in that year, it was to Gruffydd that the writ for Merionethshire was addressed by the justice. A great deal has been made of the summoning of Welsh members to English parliaments in 1322 and 1327. It has, however, been pointed out that, with regard to the parliament of 1322 , it is not known who were elected, and whether, when elected, they actually attended at York. ${ }^{42}$ In the case of the second summons we have more information, and this has an interest independent of its relevance to the story of Sir Gruffydd Llwyd. Only the writ for North Wales is extant, but in view of the precedent of 1322 there can be little doubt that similar orders were sent to South Wales as well. These writs, it must be noticed, were not issued along with those

30 Cal. of Patext Rolls, 6 August 1323, p. 335.

- Ibid., 28 September 1326, p. 325.

1 He accounts and draws pay till Michaelmas 1327: Pipe Roll 173, m. 45. He was succeded by Edmund Haclut : Brese, op. cit., p. 68.

- Tout, op. cit., p. 211, noto 2. 
addressed to the English sheriffs on 26 October 1326,43 but on 8 January 1327 - the day after parliament had assembled. ${ }^{44}$ It is clear, therefore, that the summoning of Welsh members to the parliament of 1327 was an afterthought, obviously intended to secure an exact reproduction of the assembly of 1322 .

The surviving writ is addressed to Richard Damory, justice of North Wales, and is of different form from the writs addressed to the English sheriffs. The latter were merely bidden to cause representatives to come to Westminster, the assumption being, presumably, that the method of election was sufficiently well known. Damory, on the other hand, received more precise instructions: 'Mandamus vobis quod habito avisamento cum illis hominibus de partibus predictis cum quibus melius fore videritis faciendum, sine dilatione venire faciatis,' etc. The words apparently mean, not that there was to be an election in full comitatus, but that the representatives were to be chosen by Damory himself after taking counsel with those whom he saw fit to consult. The justice's return to the writ begins, 'Venire feci ad istud parliamentum Anglicos et Wallenses infrascriptos, videlicet', followed by five paragraphs headed respectively de villa Karnarvan, de villa Belli Marisci, de villa de Conewey, de comitatu Karnarvan, and de comitatu Angleseye, each paragraph containing the names of the representatives chosen, together with their sureties. It does not seem to have been observed that the return to the Merioneth writ stands in a category by itself. It is headed, not 'de comitatu Merioneth', but simply Merionnith. The words that follow are worth attention: 'Griffinus ap Rees, miles, vicecomes de Merionnyth, cui mandatum fuit sub gravi forisfactura quod foret ad parliamentum predictum, et quod venire faceret ibidem Eygnon Vaghan' and four others named, 'returnavit preceptum ei inde directum, quod erit ad parliamentum si tempus fuerit commode. Et predictus Eynon et alii aliquam manucapcionem ad veniendum invenire nolebant'. There can be no doubt as to the meaning. Damory had, in pursuance of orders, fixed upon the sheriff and five others as representatives for Merionethshire, and sent a summons to Gruffyd bidding the six to attend in parliament. The knight's five companions declined to find sureties for their appearance - that is, in effect, refused to obey the justice's mandate. The sheriff himself replied that he would go 'if convenient', and there can be little doubt that his words were really a polite refusal. ${ }^{45}$ Gruffyd was still, therefore, a consistent partisan : he could no longer help his fallen master, but at

c Palgrave, Parliamentary Writs, II. ii. 350 . The parliement was afterwarda prorogued till 7 January 1327 : ibid., pp. 350-2.

46 Ibid., p. 364.

"Hence, whether or not the other Welsh representatives attended at Westminster, at least there were none present from Merioneth. 
any rate he could and did refuse to be present in the parliament which was to witness the final triumph of the opposing faction.

In view of the foregoing facts, the story of a rebellion must be abandoned, and with it perforce the story that Gruffydd was imprisoned as a rebel. There can be no doubt, however, that he did, in the course of his life, find himself a prisoner. The fact is established in a general way by two odes contained in the Red Book of Hergest, and attributed to a certain Gwilym Ddu. ${ }^{40}$ There seems no reason for doubting their authenticity, and internal evidence suggests that they are the work of one man and have reference to the same event. The text, indeed, is not altogether good, and it is difficult to get at the exact sense of many passages. But taken together, the two poems at all events make clear that Gruffydd was a captive, ${ }^{47}$ while the first of them seems to indicate that his prison was possibly Rhuddlan castle. ${ }^{48}$ There is also the much more important evidence, hitherto apparently unnoticed, of Gruffydd's own words contained in two petitions now in the Public Record Office $^{4 \theta}$ In one of these he complains that he has been detained in prison at Conway for more than six months on an unknown charge, and prays that he may hear the accusation, declaring his readiness to acquit himself as the king's court shall determine. In the second petition he shows that after being wrongfully imprisoned for eighteen months, again for unknown reasons, he has been released by mainprise, and prays that he may know the charges made against him, affirming that he is prepared to clear himself 'par totes les bones veyes que la court lui voet agarder'. It is thus still possible to account for the poems of Gwilym Ddu when the hypothesis of a rebellion has been rejected.

It would seem that the two petitions refer to different imprisonments. The former of them clearly belongs to the reign of Edward I, since Sir John de Havering is mentioned as justice, an office which he ceased to hold in $1301 .{ }^{50}$ The second, unfortunately, does not bear such a clear indication of date, but it

4 Jesus College, ( )xf,rd, MS.cxi, fo. 306, col. 1225-7; printed (not very accurately) in the Myvyrian Archiriling (ed. 1870), pp. 275-7. Vaughan certainly know of these poems, and it was pribably upon them that he based the story of Llwyd's imprisonment. Later writers, at any rate, always refer to them.

$47 \mathrm{He}$ is called 'Gruffydd' by name, and referred to as 'the war-dragon of Llan Rhystud' (aerdreic llan rystut), 'the lion of Tregarnedd' (llew tref garned), and 'the lord of Dinorwig' (ri dinorwec).

4T Jesus Coll. MS. oxi, fo. 3(f), col. 1225; Myvyrian Atchaiology, pp. 276-7. Such is the usual interpretation, but it is not perfectly clear. It may be noted that Vaughan said nothing about imprisonment at Rhuddan.

48 P.R.O., Ancient Petitions $75 / 3732$ and 319 E/38s. See transcripts appended below, pp. 600-1.

so He began to act on $10 \mathrm{July} 1295$, and was formally appointed on 3 September 1295: Lowis, The Hediaeval Boroughs of Snovdonia, p. 228; Cal. of Patent Rols, 3 September 1295, p. 146. He held the office until Easter 1301: Pipe Roll 146, m. 24. 
contains two phrases quite inappropriate to the reign of Edward I. Gruffydd offers to prove 'que unques ne mesprit devers nostre seignur le roi qui ore est ne devers son pere devant lui', and prays to be allowed to do so 'for the sake of the service which he has rendered to the king and his father'. The king here referred to would scarcely be Edward I, because at most Gruffydd can only have been a very small child at Henry III's death. The petition must therefore have been addressed either to Edward II or Edward III. Gruffydd's position under the former sovereign furnishes a strong prima facie case against an eighteen months' imprisonment during that reign, and the inference that it must therefore have come in that of Edward III is supported by other evidence. In October 1327 an order was issued directing the justice of Wales, or his lieutenant, to cause 'Griffin ap Roes' and twelve others named, 'lately taken at Carnarvon and imprisoned there, to be released by mainprise or for hostages to be delivered to him for them, as shall seem best to his discretion, although the king lately ordered them to be kept safely in the said prison, so that they should not be delivered without special order'.s1 The twelve companions of this 'Griffin ap Rees' seem to have been members of the native Welsh aristocracy, ${ }^{52}$ so that he was in all probability no other than Sir Gruffydd Llwyd. If so, it may be suggested that the petition refers to this imprisonment that began not very long before 26 October $1327,{ }^{53}$ and indeed the very order to release the prisoners by mainprise reminds one of the phrase in the petition-' et puis nostre seignur le roi lui fist deliverer par meynprise'.

Nor is it difficult, in view of the general circumstances of the time, to account for such measures being taken against a man like Sir Gruffydd Llwyd. The justice of Wales was the allpowerful Mortimer, and Llwyd was one of the most prominent of Edward II's friends in Wales. It may be suggested that the whole affair was simply a means of fastening a tight grip upon Gruffydd and others of the late king's Welsh adherents, who might conceivably exercise a troublesome influence among their compatriots. ${ }^{34}$ That the imprisonment, in the case of Gruffydd at least, should have lasted eighteen months, in spite of the order of 26 October 1327, is not at all surprising.

"Cal. of Clase Rollo, 26 October 1327, p. 182.

12 The names of eight appear in the return of Welsh members of parlisment earlier in the year, four as representatives, four as sureties: Palgrave, Parliamentary W rits, Loc. cif.

" If 'Griffin ap Rees' was Sir Graffydd, he cannot have been arrested much before, because he accounted and drew pay as sheriff till Michsolmas 1327 : above, p. 594 , note 41 .

s4 It is perhaps not altogether without aignificance that they should have been arrested just about the time that Edward II was put to death at Berkoley. 
The amount of bail would certainly occasion some haggling, and a phrase in Gruffydd's petition seems to suggest that the sum was fixed rather high, ${ }^{60}$ which is exactly what might have been expected, for Mortimer, presumably, would not care how long his enemy remained within the safe walls of a Welsh castle. At any rate, whether the explanation offered be correct or not, the fact that Sir Gruffydd Llwyd was a prisoner for eighteen months remains indisputable. It is to that period that the odes of Gwilym Ddu most probably refer.

His earlier confinement in the reign of Edward $I$ is an incident easier to establish but more difficult to explain. All his antecedents were strongly loyalist. His father and his uncle Hywel had fought for Edward against Llywelyn and David, ${ }^{58}$ and he himself had apparently been brought up in the household of Queen Eleanor. ${ }^{57}$ During the rebellion of 1294-5 he remained true to his allegiance, and served with the cavalry in the royal army. ${ }^{58}$ It is therefore surprising to find him petitioning the king as a prisoner in Conway castle, ${ }^{59}$ especially as the petition seems to belong to the year 1296. The only internal evidence of date is the reference to Sir John de Havering as justice, an office which he held from July 1295 to $1301,{ }^{60}$ but it is fortunately possible to supplement it from another source. In the Annales Cestrenses ${ }^{61}$ there is among the jottings under 1296 a sentence to this effect: 'Post Pascha captus fuit Griffinus Ecloyt a domino Iohanne de Haveryngys et ductus London.' The monk probably learned the fact when Havering and his captive passed through Chester on their way to London. Now Llwyd's petition is endorsed with the following answer: 'Ad parleamentum et audiatur Iusticiarius vel mandetur ei quod

" '. . a a son gref damage de mile livres et de plus.'

10 They soom to have sobmitted to Edward in 1277: Cal. o Patent Rols, 1272-81, p. 211. There is evidenoe that 'Gruffydd Llwyd's father was on no good terms with Llywelyn in 1281 : P.R.O., Liber A., fo. 337 : declaration by 'Res filius Griffud filius Edeneved' that he is bonnd on demand to pay Llywelyn 100\%. eterling 'propter inobedientiam et contemptam que nos dioto domino Principi fecimus apud Aberffraw anno Domini MCCLXXXI die Lune post festum Sancti Micheelis '. P.R.O., Ancient Petitions 168/7854 (below, p. 601) shows that this Rhys ap Gruffydd was assigned by the king after the conquest to be 'guardian of the county of Carnarvon' and 'sworn of his counsel', while Hywel, from whom Gruffydd Llwyd inherited Llanrhystud, was slain in the course of the war ' au pount de Angleseye en la compagnie Sire Otes de Granteoun'.

s7 This seems to be the meaning of 'por lalme la Reyne qi norri il esteit et lealement la servi' in P.R.O., Ancient Petitions 75/3732 (bolow, p. 600). If so, Gruffydd Llwyd's whole life was olosely connected with the court, first in the queen's household, then in that of the Prince of Wales, and finelly in that of King Edward $\Pi$.

" 'Griffynus Loyt' is one of eight Welsh equites recorded in a memorardum as receiving pay at $12 d$. per day from 15 November 1294 to 1 January following : P.R.O., Exchequer Accounts, 6/18. "P.R.O., Ancient Petitions 75/3732 (below, p. 600).

- Seo above, p. 596, note 50 .

of Fdited by R. C. Christie (Lancashire and Cheshire Reoord Society, 1887), p. 118. 
certificet regem de causa capcionis et detencionis sue in prisona.' It seems likely, therefore, that the journey to London was the outcome of the petition. When exactly it took place cannot be determined from the annalist's words. If taken literally, they mean that 'Griffinus Ecloyt' was captured after Easter, so that the journey to London could not have taken place until at least six months later, that is, about the end of 1296 . It is more probable, however, that the words refer to the time that the journey was made, the monk assuming that the arrest had come immediately before. In that case, Llwyd had been arrested at least six months before Easter 1296-that is, some time towards the close of 1295, soon after Havering's appointment as justice. On what charge he was imprisoned it is impossible to determine : the petition simply says 'par encusement et male volence de ses enemis'. Perhaps he was the victim of malicious enemies who hated him as an adherent of the English conqueror. The accusations, whatever they were, at any rate broke down, for he reappears again in the summer of 1297 a free man, accompanying the king to Flanders as leader of the footmen of North Wales. ${ }^{82}$ From that point to the death of Edward II he seems to have been a faithful and trusted servant of the crown.

Having discussed the various controversial questions raised by the evidence, it only remains to add a word on Sir Gruffydd's last years under Edward III, which were apparently the most obscure and probably the least fortunate period/of his life. Reasons have already been given for the belief that he may have suffered for his loyalty to Edward II. In 1331 he was involved, along with other Welshmen, in some quarrel, ending in violence, with certain 'Englishmen dwelling in North Wales', and two justices were commissioned to look into the matter, and imprison until further orders those who should be found guilty. ${ }^{13}$ The men of English race dwelling in North Wales would almost certainly be burgesses of one or other of the boroughs-perhaps Carnarvon. The outcome is unknown, but clearly the affair was not regarded as serious. It was probably a mere local dispute of the type that was common everywhere in the middle ages, particularly when, as in Wales, men of different race dwelt side by side. With that exception, Sir Gruffydd Llwyd's name is practically absent from the records of Edward III's reign. He was indeed summoned to join the king's army in Scotland in January 1335, but was afterwards pardoned for

- See above, p. 589, and note 5 .

- Cal. of Patent Rolls, $10 \mathrm{May}$ 1331, p. 143. The only one of Llwyd's companions named is David ap Adda, who, it may be noticed, was one of those arrested in 1327, and was also among those chosen to attend parliament as representatives of Camarvon county in January of that year. 
non-attendance. ${ }^{o 4}$ He was still alive at the end of May in that year, but six weeks later he was dead. ${ }^{65}$

In his day he had been one of the most conspicuous of the Welshmen, who, accepting the settlement of 1284, were content to play their part by assisting in the practical application of the administrative system set up by Edward I. His long life contains much indeed that is interesting, much, doubtless, that was adventurous, but nothing that can be called heroic. $\mathrm{He}$ was just plain Gruffydd ap Rhys, knight, commissioner of array, sheriff, and royal partisan. He was no martyr in a national cause; on the contrary, both to the conqueror of Wales and to his son he was always ' a loyal Welshman of Snowdon '.68

J. G. Edwards.

\section{APPENDIX}

I

Ancient Petitions 75/3732.

A nostre seignor le Rey et a son conseil mustre Griff. Thloyt, son leal Galeys de Snawdon, qe Sire Joh. de Haveringe li ad pris et en forte prison mis et detenu a Conewey demi an passe et plus, et il ne seet por quey ne par quel encheson, dunt il prie a nostre seignor le Rey por Deu et por lalme la Reyne qi norri il esteit et leslement la servi, qil pusse aver son respons de totes choses dunt hom le ad encuse al Rey, et de quant qe hom savera dire vers li ; et il est prest dest a la ley et de sei aquiter par quantque la ourt le Rey agardera, salve ses noeffis [?], qil ne ad chose fete ne dite por quei il deive estre pris ne enprisone ne tiele duresce suffrir : et derichef crie merci a nostre seignor le Rey qe por lalme la Reyne, qi hom il esteit, qe pite preigne de li qil ne seit en tiele manere retenu en forte prison par encusement et male volence de ses enemis sanz respons aver.

\section{Bindorsed]}

Ad parleamentum et audiatur Iusticiarius vel mandetur ei quod certificet regem de causa capcionis et detencionis sue in prisona.

Ancient Petitions $319 \mathrm{E} / 388$.

A nostre seignur le Roi et a son conseil moustre Griffith Thloyt son bachiler qil ad este enprisone atort et saunz desert, et puis detenu en la prisone nostre seignur le Roi par un an et demy, a son gref damage de mile livres et de plus, et il ne seet la encheson pur quoi ne unques ne poeit savoir ; et puis nostre seignur le Roi lui fist deliverer par meynprise ; et de ceo qil est prest a respoundre par voie de ley et de reson a touz ceaux qui saverount dir ou monstrer nule encheson devers lui par quei len lui deust fere tiele duresse, et auxi qil est prest de lui aoquiter par totes bones veyes que la court lui voet agarder que unques ne mesprit

it Rotuli Scotione, i. 311-12, 333-4.

* Cal. of Patent Rolls, 28 May 1335, p. 106 ; Cal. of Inquisitiones Past Mortem, vii. 453. The writ for the inquisition is deted 12 July.

- Beo below, Appendiri. 
devers nostre seignur le Roi qui ore est ne devers son pere devaunt lui par quei qil doust ensi estre demene, eins les ad servi en tout son temps bien et leaument en guerre et en pees; et pur ceo prie le dit Griffith au dit nostre seignur le Roi et a son conseil, pur Dieu et pur le service qil ad fait a son pere et a lui, que il voille de sa grace mettre tiele remedie sur les dites grevannces et damages que reson et dreiture demandent, et que de la avant dite meynprise puis estre quites.

[Endorsed]

Coram ipso Rege.

Coram Rege et magno consilio.

\section{Anaient Petitions 168/7854.

A nostre seignor le Rey, qi Dier gard, et a son consail mustre son bachiler Griffutz ap Rees qe come Howel ap Griffutz, chivaler, son uncle, frere a Res ap Griffutz son piere, morust el service le Roi piere a nostre seignor le Roi qi ore est au pount de. Angleseye en la compagnie Bire Otes de Grantsoun en la guerre Lewel et David, et puis apres le conquest le dit Res ap Griffutz son frere, et piere al dit Griffutz, fut assigne depar le Roy de estre gardein del countee de Caernarvon et jurez de son consail, et en cel estat morust, sicome le Compte de Nichole, le dit Sire Otes et autres grands seignors qui adonq furent du consel le dit Roi sevent bien et lesument ferunt temoigner; en quex temps Thomas de Bek adonq evesç de Seint David, predecessour al evescg qi ore est, purchaca de doun le Roi par chartre ${ }^{1}$ totes les avoesons del counte de Cardigan dount les patrons furent desheritez pur lour forfet en la dite guerre, en quele chartre leglise de Lanrustud en le dit countee est contenue entre les autres eglises, par une fause suggestion fete au dit Rroy et a son consail, la quele eglise fut del avoeson et patronage le dit Howel ap Griffutz et ses ancestres. du temps dont memore ne curt sanz interruption, quel dreit de la dite eglise ensemblement od la tere le dit Howel es dites parties vinct als purpartie le dit Griff. ap Res qui ore est par partison fete entre ly et les heirs le dit Howel son uncle, selono le usage et la ley de Gales; orervient levesca du dit lieu et cleime lavoeson de la dite eglise par my la dite suggestion, la quele ne fu unques forfete por ceq les patrons suzditz morurent en la pes le Roy come est suzdit, et le dit Griffutz ap Res ne forfét ne trespassa unques dever nostre seignur le Roy ore ne dever le piere par quoi il. devereit perdre lavoeson ne son dreit del eglise suzdite; dont le-dit Griffutz prie a nostre dit seignor le Roy pur Diex et pur les almes ses auncestres si luy plest de sicome notoire chose est et aperte que ses auncestres avanditz morurent en la fourme sudite, que ly pleise fere: ordener ancune voie que le dit Griffutz ne seit desheritez de son dreit'sanz:reson, car ceo sereit charge et peril al alme son piere dont Diex defend. ${ }^{2-}$

1 Soo Calliof Charter Rolts, ii. 275 (10 June 1284).

2 The dispute was settled in 1309, when Sir Gruffydd sold to the bishop of St. Dspids his right to the edvowson of the church of Llanrhystad : Bridgeman, Biotory, of the Princes of South Wales, p. 231. 